\title{
Helping hand of biotechnology in conservation of medicinally important plant (Asparagus racemosus)
}

\author{
H.M. SHERATHIY, R.V. KOTHIYA, B.J. MALVIYA AND P.V. SORATHIYA
}

Department of Biotechnology, Shree Manibhai and NavalbenVirani Science College, RAJKOT (GUJARAT) INDIA

Email : hiren.sherathiya@gmail.com

\begin{abstract}
Increase in human population, urbanization, cutting trees and use of plants for pharmaceutical purpose leads to destruction of medicinal plant. Not only destruction but some of the species become threaten for their existence. One of them is Asparagus racemosus whose roots and its extracts widely used for the preparation of medicines by the pharmaceutical companies. That's why, conservation efforts have been required which can be achieved with the help of various plant biotechnological techniques such as suspension culture. Not only for the conservation, it provides an alternative way of producing large amount of active compound directly in to the laboratory. For the establishment of suspension culture techniques a prime requirement is to have a standardize protocol for callus culture. This paper represents optimization of protocol for callus culture and suspension culture from Asparagus racemosus. It has been proved that the plant hormones play vital role for callus induction. In this work MS Medium with different combination of auxin (NAA, 2, 4 D) and cytokinines (BAP, Zeatin, Kinetin) have been tried for callus induction. The best friable callus induction, highest callus induction rate and excellent callus growth were obtained in MS medium supplemented with $1.0 \mathrm{mg} / \mathrm{L}$ ZEATIN $+0.1 \mathrm{mg} / \mathrm{L}$ BAP. Same medium was then utilized for the establishment of suspension culture. In cell suspension culture of $A$. racemosus, the maximum growth $(7.7 \mathrm{~g} / \mathrm{l})$ were observed in suspension culture initiated from leaf explant and the highest saponin production $(0.580 \mathrm{mg} / \mathrm{g})$ were obtained from the biomass of suspension culture initiated from root explant at 18 days after culture.
\end{abstract}

Key words : Callus culture, Suspension culture, Secondary metabolites

How to cite this paper : Sherathiy, H.M., Kothiya, R.V., Malviya, B.J. and Sorathiya, P.V. (2014). Helping hand of biotechnology in conservation of medicinally important plant (Asparagus racemosus). Asian J. Bio. Sci., 9 (2) : 178-187. 